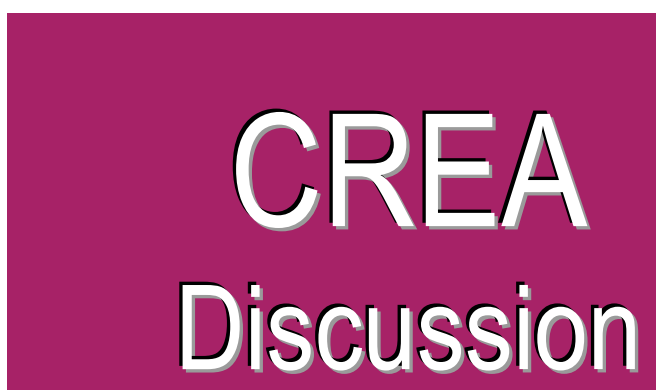
Paper 2018-18 Economics

\title{
Corruption and tax compliance: Evidence from small retailers in Bamako, Mali
}

available online : http://wwwfr.uni.lu/recherche/fdef/crea/publications2/discussion_papers

Luisito Bertinelli, CREA, University of Luxembourg Arnaud Bourgain, CREA, University of Luxembourg

Florian Leon, CREA, University of Luxembourg

October, 2018

For editorial correspondence, please contact: crea@uni.lu

University of Luxembourg

Faculty of Law, Economics and Finance

$162 \mathrm{~A}$, avenue de la Faïencerie

L-1511 Luxembourg 


\title{
Corruption and tax compliance: Evidence from small retailers in Bamako, Mali
}

\section{Luisito Bertinelli ${ }^{1}$, Arnaud Bourgain ${ }^{1 *}$ and Florian Léon ${ }^{1}$}

October 2018

\begin{abstract}
We investigate the impact of corruption on tax compliance using a sample of 700 small business in Bamako, Mali. Our results show that paying bribes reduced tax compliance by almost ten percentage points.
\end{abstract}

Keywords: Tax compliance, Corruption, Informal sector; Micro-enterprises; Africa; Mali

JEL Classification : H26, H32, D73

${ }^{1}$ CREA, University of Luxembourg, 162a avenue de la faïencerie, L-1511 Luxembourg.

Emails : luisito.bertinelli@uni.lu; arnaud.bourgain@uni.lu; florian.leon@uni.lu

*corresponding author

We would like to thank Abdoulaye Tounkara, Fabiana d'Andria and Leeli Ball for their assistance as well as Oumar Kaba Diakite for their useful comments. Any remaining errors are our own. 


\section{Introduction}

This study aims to measure the impact of corruption on tax compliance by small retailers in Bamako (Mali), controlling for possible confounding factors and mismeasurement. Rates of (direct) tax mobilization are known to be particularly low in Sub-Saharan Africa (Abramovsky et al 2014; Gordon and Li 2009), and much lower in the informal sector (Joshi et al 2014), which is the focus of our study. Corruption negatively influences the tax payment through two channels. First, some individuals or firms can pay bribes to reduce or avoid tax payment. Bribes are viewed as a substitute for tax payments. Second, fiscal contract theories (cf Andreoni et al 1998; Timmons and Garfias 2015) posit that tax yields depend on agents' willingness to accept them. Consequently, generalized corruption for public service procurement reduces the willingness to accept tax payment.

In addition to cross-country studies using perception indicators of corruption or tax morale (e.g., Torgler 2005; Richardson 2009; Attila et al. 2009; Lago-Peñas and Lago-Peñas 2010), econometric studies at the firm level are scarce. Alm et al (2016); and Gauthier and Goyette (2014) obtained the negative impact of corruption on tax compliance using extensive firm surveys of the World Bank. However, these studies are based on relatively large and formal firms. For instance, in the sample of Ugandan firms used by Gauthier and Goyette (2014), the average number of employees is 124 . By contrast, our work contributes to this burgeoning literature by relying on the results of an original survey focusing on 700 micro enterprises, essentially informal or semi-formal, in the retail sector of a huge and poor African city. We show that corruption always deters tax payments, and these results are robust to various tax compliance indicators after controlling for the potential endogeneity of corruption.

\section{Data and variables}

The survey: Data were retrieved from face-to-face interviews conducted with 700 micro retailers in Bamako in October and November 2016. Our sample includes a large proportion of informal or semiformal micro enterprises, which by definition cannot be drawn at random from an official list of retailers registered in the Malian statistical office. Following the "Intercept point survey" method (McKenzie and Mistiaen, 2009), our sampling scheme attempts to respect the geographical and sectoral concentrations of retail activities in Bamako.

Dependent variable: Our main indicator representing tax compliance is a binary measure, signaling the payment of direct taxes. In Mali, the normal rate of corporate income tax is $30 \%$ but small firms are subject to a "synthetic tax" based on turnover (Rota-Graziosi et al. 2014). Our survey also provides 
information on the amounts of tax payments, but we casted serious doubts about the accuracy of these amounts. As an additional measure of tax compliance, we relied an indicator based on the registration of the retailer with the tax authority (Tax_regist).

Independent variables: The payment of bribes, declared by survey respondents, is our main explanatory variable of interest. It is worth mentioning that we had a response rate of 89.3 per-cent (possibly excluding selection bias), of which 13 per-cent declared that they have paid bribes in the past.

Drawing on literature regarding the drivers of formality and taxation, we include the following individuallevel variables (chiefs of retail unit): Female, with value 1 indicating that the retailer is a woman and 0 for a man; Age, continuous variable; Educ_Second for interviewees that attended high school or university; Close_to_admin Existence of a close family member in public administration. Further, we included business-level characteristics: the firm size (Size) variable is measured as the logarithm of the firm's turnover; Employment represents the total number of employees; Other_activities, is a binary variable that takes a value of 1 if the retailer developed other activities; Multi_activities, takes a value of 1 if the retailer manages several businesses; Tax_audit is a dummy variable taking value a value of 1 if the retailer has experienced a tax audit during the recent past; Fixed_premises is a dummy variable with a value of 1 for if the business is located in fixed business premises and 0 otherwise; and Industry effects are the retail sub-sector dummy variables: food, textiles, electrical products, various equipment, multiple products and others.

\section{Empirical Methodology}

To measure the impact of corruption on the propensity to pay corporate taxes, we use the following specification:

$$
P\left(\operatorname{tax}_{i}=1\right)=\Phi\left(\beta_{0}+X_{i} \beta\right),
$$

where $i$ denotes the retailer, and $X$ is a vector of covariates (as listed in section 2), including our measure of corruption. Given the binary nature of our dependent variable, we rely on a probit model to estimate the $\beta$ parameters, and hence, $\Phi$ is the standard normal cumulative density function.

As the tax payment and the corruption data are based on self-reporting, we faced a serious issue of overor understatement of the actual values. While the former introduces noise in our estimates, the latter may bias our results. We address tackle in the following manner: first, as an alternative to the "tax payment" variable, we use the information on registration at the tax administration to proxy the fact of paying taxes. Second, we instrument the corruption variable (i.e., declared active corruption by the 
survey respondent) with a variable of corruption perception (i.e. does the survey respondent consider corruption to be more important in her sector than in others). Both corruption variables were significantly correlated $\left(0.41^{* * *}\right)$, and take the same value in 85 per cent of the cases.

\section{Results}

Table 1 displays the determinants of tax compliance. In columns (1) to (3), we focus on our preferred measure of tax compliance based on tax payment. In the first column, we report the marginal effects of simple probit estimations for the whole sample (appropriately adjusted in case of binary explanatory variables). Our results highlight that corruption has a negative and statistically significant effect on tax compliance. The same result holds in column (2), when we restrict our sample to observations that are also available for our instrument. The results remain unchanged.

To control for endogeneity, we instrument our corruption variable as explained in the previous section. The results are displayed in column (3). The F-value of the first stage reported at the bottom of the table dispels the weak instrument eventuality. We confirm that corruption has a negative and significant impact on tax compliance. Corruption is not only statistically significant but also economically sizeable. On average, two thirds of the surveyed retailers comply with tax payment in our sample. However, paying bribes reduced this ratio by 20 percentage points.

In columns (4) to (6), we provide a robustness check by employing an alternative dependent variable for tax payment. As mentioned in the previous section, registration with the tax authority is not perfectly correlated with tax payment. Almost one quarter of firms that are registered with the tax authority do not pay taxes (the opposite occurs as well but is rarer). The results with our alternative indicator of tax compliance confirm our main findings. Corruption is negatively associated with tax compliance. The economic impact is also far from negligible. While 85 per cent of the firms are registered with tax authorities, paying bribes reduced this likelihood by almost ten percentage points.

Finally, we observe that control variables are often in line with predictions. In particular, larger firms, fixed businesses and those that experienced a tax audit are more likely to comply.

\section{Conclusion}

Our study investigates the determinants of tax compliance of micro-enterprises in Africa using a survey of 700 retailers in Bamako, Mali. Two major conclusions can be drawn. First, contrary to a common belief, a significant number of small firms pay taxes. Second, corruption provides a way to avoid complying with tax requirements or is considered as a substitute thereof. 


\section{References}

Abramovsky L., Klemm A., Phillips D., 2014, Corporate Tax in Developing Countries: Current Trends and Design Issues, Fiscal Studies 35(4), 559-588.

Alma J., Martinez-Vazquez J., McClellan Ch., 2016, Corruption and firm tax evasion, Journal of Economic Behavior \& Organization 124, 146-163.

Andreoni, J., Erard, B. Feinstein, J., 1998. Tax compliance, Journal of Economic Literature 36 (2), 818-860.

Attila G., Chambas G., Combes J-L, 2009, Corruption et mobilisation des recettes publiques : une analyse économétrique, Recherches économiques de Louvain 75(2), 229-268.

Gauthier B., Goyette J, 2014, Taxation and corruption: theory and firm-level evidence from Uganda, Applied Economics 46 (23), 2755-2765.

Gordon, R. and Li, W., 2009, Tax structures in developing countries: many puzzles and a possible explanation, Journal of Public Economics 93, 855-66.

Joshi A., Prichard W., Heady Ch., 2014, Taxing the Informal Economy: The Current State of Knowledge and Agendas for Future Research, The Journal of Development Studies 50(10), 1325-1347.

Lago-Peñas, I., Lago-Peñas, S., 2010, The determinants of tax morale in comparative perspective: Evidence from European countries, European Journal of Political Economy, 26(4), 441-453.

McKenzie D. J., Mistiaen J. 2009, Surveying Migrant Households: A Comparison of Census-Based, Snowball and Intercept Point Surveys, Journal of the Royal Statistical Society: Series $A$ (Statistics in Society) 172(2), 339-60.

Richardson, G. 2006, Determinants of tax evasion: A cross-country investigation, Journal of International Accounting, Auditing and Taxation, 15(2), 150-169.

Rota-Graziosi G., Geourjon A-M, Ménard G., 2014, Mali : Politique fiscale (diagnostic), Rapport d'assistance, FMI, September.

Timmons, J. and Garfias F., 2015, Revealed Corruption, Taxation, and Fiscal Accountability: Evidence from Brazil, World Development 70, 13-27.

Torgler, B., 2005, Tax morale in Latin America, Public Choice 122, 133-157.

Williams, C. C., Shahid, M. and Martinez, A. (2016), Determinants of the level of informality of informal micro-enterprises: Some evidence from the city of Lahore, Pakistan, World Development 84: 312-325. 
Table 1: Determinants of tax compliance

\begin{tabular}{|c|c|c|c|c|c|c|}
\hline & \multicolumn{3}{|c|}{ Tax payment } & \multicolumn{3}{|c|}{ Tax authority registration } \\
\hline & $\begin{array}{l}\text { probit } \\
\text { All }\end{array}$ & $\begin{array}{l}\text { probit } \\
\text { Rest. }\end{array}$ & $\begin{array}{l}\text { IV-probit } \\
\text { Rest. }\end{array}$ & $\begin{array}{l}\text { probit } \\
\text { All }\end{array}$ & $\begin{array}{l}\text { probit } \\
\text { Rest. }\end{array}$ & $\begin{array}{l}\text { IV-probit } \\
\text { Rest. }\end{array}$ \\
\hline & (1) & (2) & (3) & (4) & (5) & (6) \\
\hline Corruption & $\begin{array}{l}-0.1653^{* * *} \\
(-3.45)\end{array}$ & $\begin{array}{l}-0.1672 * * * \\
(-3.37)\end{array}$ & $\begin{array}{l}-0.2012^{* * *} \\
(-3.28)\end{array}$ & $\begin{array}{l}-0.0663^{*} \\
(-1.75)\end{array}$ & $\begin{array}{l}-0.0837^{* *} \\
(-2.01)\end{array}$ & $\begin{array}{l}-0.0485^{* * *} \\
(-2.66)\end{array}$ \\
\hline Age & $\begin{array}{l}0.0056^{* * *} \\
(2.98)\end{array}$ & $\begin{array}{l}0.0042^{* *} \\
(1.96)\end{array}$ & $\begin{array}{l}0.0061 * \\
(1.85)\end{array}$ & $\begin{array}{l}0.0015 \\
(1.13)\end{array}$ & $\begin{array}{l}0.0002 \\
(0.17)\end{array}$ & $\begin{array}{l}0.0003 \\
(0.22)\end{array}$ \\
\hline Educ_Second & $\begin{array}{l}-0.0437 \\
(-1.11)\end{array}$ & $\begin{array}{l}-0.0726 \\
(-1.55)\end{array}$ & $\begin{array}{l}-0.0874 \\
(-1.39)\end{array}$ & $\begin{array}{l}0.0058 \\
(0.21)\end{array}$ & $\begin{array}{l}-0.0324 \\
(-1.01)\end{array}$ & $\begin{array}{l}-0.0166 \\
(-0.89)\end{array}$ \\
\hline Female & $\begin{array}{l}-0.0632 \\
(-1.34)\end{array}$ & $\begin{array}{l}-0.0262 \\
(-0.46)\end{array}$ & $\begin{array}{l}-0.0528 \\
(-0.22)\end{array}$ & $\begin{array}{l}-0.0592^{*} \\
(-1.85)\end{array}$ & $\begin{array}{l}-0.0385 \\
(-1.16)\end{array}$ & $\begin{array}{l}-0.0344 \\
(-1.17)\end{array}$ \\
\hline Close_to_admin & $\begin{array}{l}0.0755^{* *} \\
(2.08)\end{array}$ & $\begin{array}{l}0.0282 \\
(0.70)\end{array}$ & $\begin{array}{l}0.0404 \\
(0.72)\end{array}$ & $\begin{array}{l}-0.0204 \\
(-0.89)\end{array}$ & $\begin{array}{l}0.0100 \\
(0.39)\end{array}$ & $\begin{array}{l}0.0061 \\
(0.42)\end{array}$ \\
\hline Size & $\begin{array}{l}0.0650 * * * \\
(4.24)\end{array}$ & $\begin{array}{l}0.0477^{* * *} \\
(2.57)\end{array}$ & $\begin{array}{l}0.0731^{*} \\
(1.78)\end{array}$ & $\begin{array}{l}0.0330 * * * \\
(2.93)\end{array}$ & $\begin{array}{l}0.0182 \\
(1.43)\end{array}$ & $\begin{array}{l}0.0124 \\
(0.66)\end{array}$ \\
\hline Employment & $\begin{array}{l}0.0029 \\
(0.35)\end{array}$ & $\begin{array}{l}0.0028 \\
(0.31)\end{array}$ & $\begin{array}{l}0.0434 \\
(0.15)\end{array}$ & $\begin{array}{l}0.0117 \\
(1.27)\end{array}$ & $\begin{array}{l}0.0153 \\
(1.46)\end{array}$ & $\begin{array}{l}0.0083^{*} \\
(1.90)\end{array}$ \\
\hline Other_activities & $\begin{array}{l}0.0349 \\
(0.94)\end{array}$ & $\begin{array}{l}0.0508 \\
(1.17)\end{array}$ & $\begin{array}{l}0.0825 \\
(0.98)\end{array}$ & $\begin{array}{l}0.0055 \\
(0.22)\end{array}$ & $\begin{array}{l}0.0067 \\
(0.24)\end{array}$ & $\begin{array}{l}0.0057 \\
(0.04)\end{array}$ \\
\hline Multi_activities & $\begin{array}{l}-0.1635^{* * *} \\
(-3.77)\end{array}$ & $\begin{array}{l}-0.1003^{* *} \\
(-2.04)\end{array}$ & $\begin{array}{l}-0.1653^{* *} \\
(-1.96)\end{array}$ & $\begin{array}{l}0.0881^{* * *} \\
(2.56)\end{array}$ & $\begin{array}{l}0.0792 * * \\
(2.17)\end{array}$ & $\begin{array}{l}0.0443^{*} \\
(1.94)\end{array}$ \\
\hline Tax_audit & $\begin{array}{l}0.0997^{* *} \\
(2.37)\end{array}$ & $\begin{array}{l}0.2759 * * * \\
(3.95)\end{array}$ & $\begin{array}{l}0.3845^{* * *} \\
(4.53)\end{array}$ & $\begin{array}{l}0.0896 * * * \\
(2.98)\end{array}$ & $\begin{array}{l}0.0654^{*} \\
(1.67)\end{array}$ & $\begin{array}{l}0.0640 * * \\
(2.45)\end{array}$ \\
\hline Fixed_premises & $\begin{array}{l}0.2582^{* * *} \\
(3.77)\end{array}$ & $\begin{array}{l}0.1904^{* *} \\
(2.26)\end{array}$ & $\begin{array}{l}0.4989 * \\
(1.64)\end{array}$ & $\begin{array}{l}0.3051^{* * *} \\
(4.77)\end{array}$ & $\begin{array}{l}0.03894 * * * \\
(4.12)\end{array}$ & $\begin{array}{l}0.3715^{* * *} \\
(3.30)\end{array}$ \\
\hline $\begin{array}{l}\text { Industry } \\
\text { dummies }\end{array}$ & Incl. & Incl. & Incl. & Incl. & Incl. & Incl. \\
\hline Obs. & 548 & 388 & 388 & 552 & 343 & 343 \\
\hline Pseudo R2 & 0.35 & 0.36 & - & 0.56 & 0.60 & - \\
\hline F-1st (excl. IV) & & & 49.14 & & & 39.44 \\
\hline Wald-test & & & $3.25^{*}$ & & & 2.03 \\
\hline
\end{tabular}

The dependent variable is a dummy equals to one if a firm pays a direct tax in columns (1) to (3); and, a dummy equals to one if a firm is registered with tax authority in columns (4) to (6). Table reports marginal effects and associated z-score in parentheses. ${ }^{* * *}, * * *$ denote an estimate significantly different from 0 at the $10 \%, 5 \%$ or $1 \%$ level. 